\title{
Impact of land uses on water quality in Malaysia: a review
}

\author{
Moriken Camara ${ }^{1}$, Nor Rohaizah Jamil ${ }^{1^{*}}$ (D) and Ahmad Fikri Bin Abdullah ${ }^{2}$
}

\begin{abstract}
Land use changes in urbanization, industrialization, and agricultural processes will continue to have negative impacts on water quality at all scales. The impact of land use changes on water quality is generally studied by analyzing the relationships between land use and water quality indicators. Therefore, the purpose of this research was to review and analyze the main relationships between land use and water quality, as well as to visualize the major sources and processes of water quality pollution in Malaysia. To achieve our goal, we evaluated the significance of both land use and water quality attributes used in the past studies and correlated them to understand their relationship from another angle of view. The results revealed that $87 \%$ of the reviewed studies indicated urban land use as a major source of water pollution, while $82 \%$ indicated agricultural land use, $77 \%$ indicated forest land use, and $44 \%$ indicated other land uses. However, the results of correlation analysis showed that agricultural and forest-related activities more affected water quality through their significant positive correlation with physical and chemical indicators of water quality, while urban development activities had a greater impact on water quality through altering hydrological processes such as runoff and erosion. These findings would provide decision-makers with useful information for managing water pollution processes rather than sources only.
\end{abstract}

Keywords: Land use, Water quality, Malaysia

\section{Introduction}

Land use is the human use of terrestrial space for economic, residential, recreational, conservation, and government purposes. The concept of land use is closely linked to the development of the human community. Patterns of social development and land use have shaped the local and global environment since prehistoric times (Encyclopedia 2009). Current patterns of development, as well as the characteristics of the natural environment and the consequences of past development activities, determine opportunities for future development and also the need to restore or improve environmental resources (Encyclopedia 2009). Land use refers to anthropogenic use of lands and their resources, and the physical conditions of these lands result from a long-term interaction between humans and natural environment.

Water quality is defined as a measure of water use for different purposes (drinking, industrial, agricultural,

\footnotetext{
*Correspondence: norrohaizah@upm.edu.my

${ }^{1}$ Faculty of Environmental Studies, Universiti Putra Malaysia UPM, 43400

Serdang, Selangor, Malaysia

Full list of author information is available at the end of the article
}

recreational, and habitat) using various parameters such as physical, chemical, and biological (Giri and Qiu 2016). Water quality plays a central role in all aspects of living organisms on the earth, attracting the attention of a broad range of scientists, researchers, and water resource managers. Water quality varies according to location, time, weather, and sources of pollution (Giri and Qiu 2016). Preserving water quality is an arduous task, mainly because of the presence of point and non-point sources (NPS) of pollution. NPS pollution involves a natural process that can never be totally eliminated. Human activity can, however, have a significant influence on the acceleration or deceleration of pollution rate at the source; therefore, in dealing with non-point source pollution, the challenge is to identify activities that result in significant degradation of water quality and design control programs to minimize problems (Baird et al. 1996). Browne in 1989 described a definition of NPS pollution that includes the following factors:

- Non-point sources are spread, cover important areas, and operate either in response to human 
activities or as "background pollution" of natural lands.

- Non-point source pollution is related to land management and geological and hydrological variables and may change daily or annually. Only land management factors can be controlled by society.

- Non-point sources are produced and transported as part of the hydrological cycle. Surface runoff transports eroded soil particles from porous areas. It also absorbs and transports contaminants deposited in impervious areas. Groundwater transports pollutants from septic tanks and landfills.

- Urban runoff contains suspended solids, metals, bacteria, aerobics, nutrients, and fats. Sources of these pollutants comprise vehicles, fertilizer and pesticide applications, animal manure, construction activities, and road pickling.

- Non-urban pollutants are often associated with agricultural activities. Agricultural pollutants comprise pesticides, sediments, nutrients, and organic substances. The NPS load in agricultural areas is usually seasonal, with higher loads associated with planting and harvesting activities.

Furthermore, land use changes in the process of urbanization, industrialization, and agriculture can change the surface characteristics of watersheds that affect the quality and quantity of runoff. The impact of land use changes on water quality involves association of land use and water quality indicators (Tu 2011). Many studies have shown that there are significant correlations between land use and water quality indicators (Baker 2003; Buck et al. 2004; Li et al. 2008; Tong and Chen 2002). These studies of relationship between land use and water quality through various means and approaches have permitted to estimate and understand water quality in rivers distressing from diffuse pollution. In general, the higher percentages of land use associated with human activities and economic development in watersheds are often interrelated with high concentrations of water pollutants, while undeveloped areas such as natural forest areas are linked with good water quality. However, knowledge in such relationships at a catchment scale across seasons is still lacking due to the large area and monitoring difficulties (Rodrigues et al. 2018).

In Malaysia, pollution of river waters poses a serious risk to the health of the public. River water quality monitoring is the responsibility of the Department of Environment (DOE) in Malaysia. According to DOE (2018), the monitoring program of DOE began in 1978 for Peninsular Malaysia. In 1985, Sabah and Sarawak were included in the monitoring program, and this was followed by the Island's Marine Water Quality
Monitoring Program in 1998. Currently, 233 coastal and estuarine monitoring stations are established in all states of Malaysia and 73 islands with 86 stations for the island monitoring program DOE (2018). These islands are categorized into four, namely, development islands, resort islands, protected islands, and marine park islands. The monitoring program includes in situ measurements of water quality parameters such as $\mathrm{pH}$, temperature, dissolved oxygen, turbidity, conductivity, and salinity, as well as laboratory analyses of parameters such as Escherichia coli, cadmium, copper, mercury, and lead. The sampling frequency is between four and six times a year. This monitoring activity provides important information on the state of water quality of different water bodies (DOE 2018).

This research is motivated by the fact that human activities such as rapid urbanization, intensive agriculture, and deforestation in Malaysia have increased land use changes and their impacts on water quality all over the country. As such, many studies have been conducted to address these problems; therefore, this research was necessary to accommodate the main findings of those previous studies, in order to facilitate researchers to identify specific areas requiring improvements and priorities. Razali et al. (2018) reviewed case studies of land use change in highland areas and its impact on river water quality, and their study was limited to the river system network in the Cameron Highlands in Malaysia. However, the purpose of the present research was to review and analyze the main relationships between land use and water quality, as well as to visualize the major sources and processes of water quality pollution in Malaysia.

\section{Methodology}

In order to identify the relevant existing literature in accordance with the purpose of this study, a rigorous review of all applicable studies conducted in Malaysia until mid-2018 was done. The literature search was conducted in the main scientific databases, including Scopus, ScienceDirect, Springer, Google Scholar, and EZproxy from Universiti Putra Malaysia (UPM), with the following keywords: Land use, water quality, and Malaysia. From this search, the focus was on the articles that enabled to identify both land use and water quality variables utilized in the different studies (Fig. 1). In total, 39 of 52 analyzed articles made it possible to extract the needed information. In this study, we addressed the relationship between land use and water quality variables by checking how the attribute variables were correlated as extracted from the literatures examined over a 10-year period (Figs. 3 and 4). After quantifying the attribute variables, we chose to use the Spearman correlation coefficient instead of the Pearson correlation coefficient which is the 


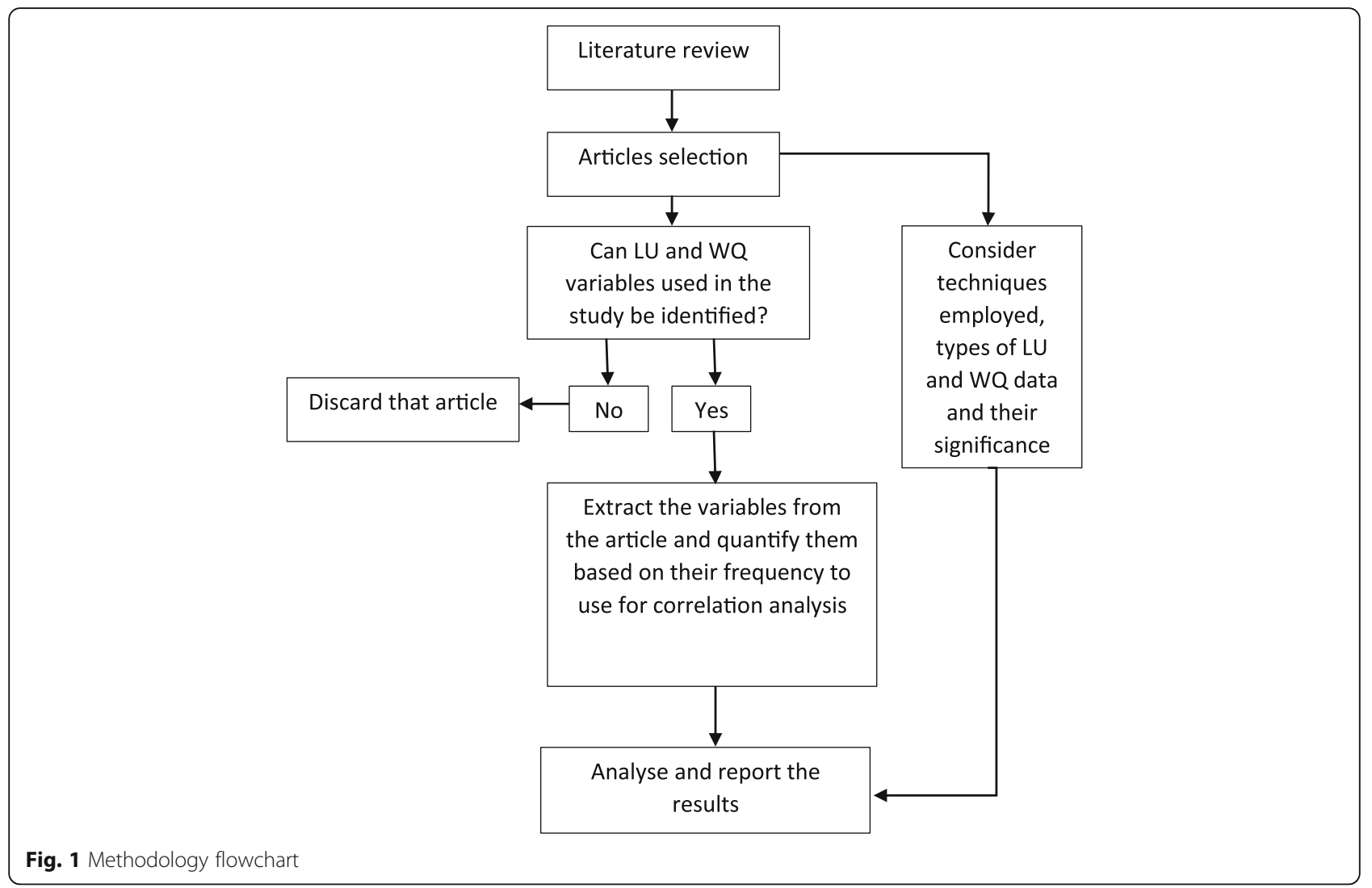

most common for continuous data. However, the study involved no data collection or laboratory water quality analysis. In this study, the land use attributes were grouped into three major categories according to level I from Anderson (1976) classification scheme. Urban land includes residential (built-up), industrial, commercial, and recreational areas; agricultural land comprises oil palm and rubber plantations, croplands, pastures, and other farming areas; and forest land involves logging area, mangrove area, and wetland. On the other hand, water quality attributes were grouped into four types: physical, chemical, biological, and hydrological. However, for the sake of simplification, water bodies, barren land, and abandoned/mining areas were all grouped into one category (Fig. 3). These types of land use were not discussed in the findings due to the insignificance of literatures containing them.

\section{Results and discussion}

Techniques to analyze land use impact on water quality

Field measurements and laboratory analyses are the main methods for generating water quality data of respective water bodies. However, several studies, in addition to the data collected in the field, have used data generated by the Department of Environment (DOE) in Malaysia. The DOE sampling frequency is between four and six times a year. Moreover, various techniques have been applied in assessing and understanding the relationship between land use and water quality in different watersheds in Malaysia (Table 1). These techniques include multivariate statistics (e.g., Chow et al. 2013; Ngah and Yusri 2007), remote sensing and geographic information systems (GIS), and hydrologic/water quality modeling (e.g., Azyana and Na 2012; Vijaindra et al. 2003; Sakai et al. 2017). These techniques are commonly used for regulatory, monitoring, planning, and exploration purposes. However, the overall results of the papers analyzed in this study indicated that most researchers used modeling rather than monitoring techniques to determine the relationship between land use and water quality. These results are in line with the finding of Abdulkareem et al. (2018) who highlighted the growing of modeling approaches among Malaysian researchers to address a variety of water-related issues in Malaysia. Furthermore, in establishing the relationship between land use and water quality, modeling techniques may have some advantages over other techniques due to their suitability in relating the phenomena. As such, statistical modeling may be preferable to physical-based modeling because of the need for a large number of input data associated with continuous observation data for the 


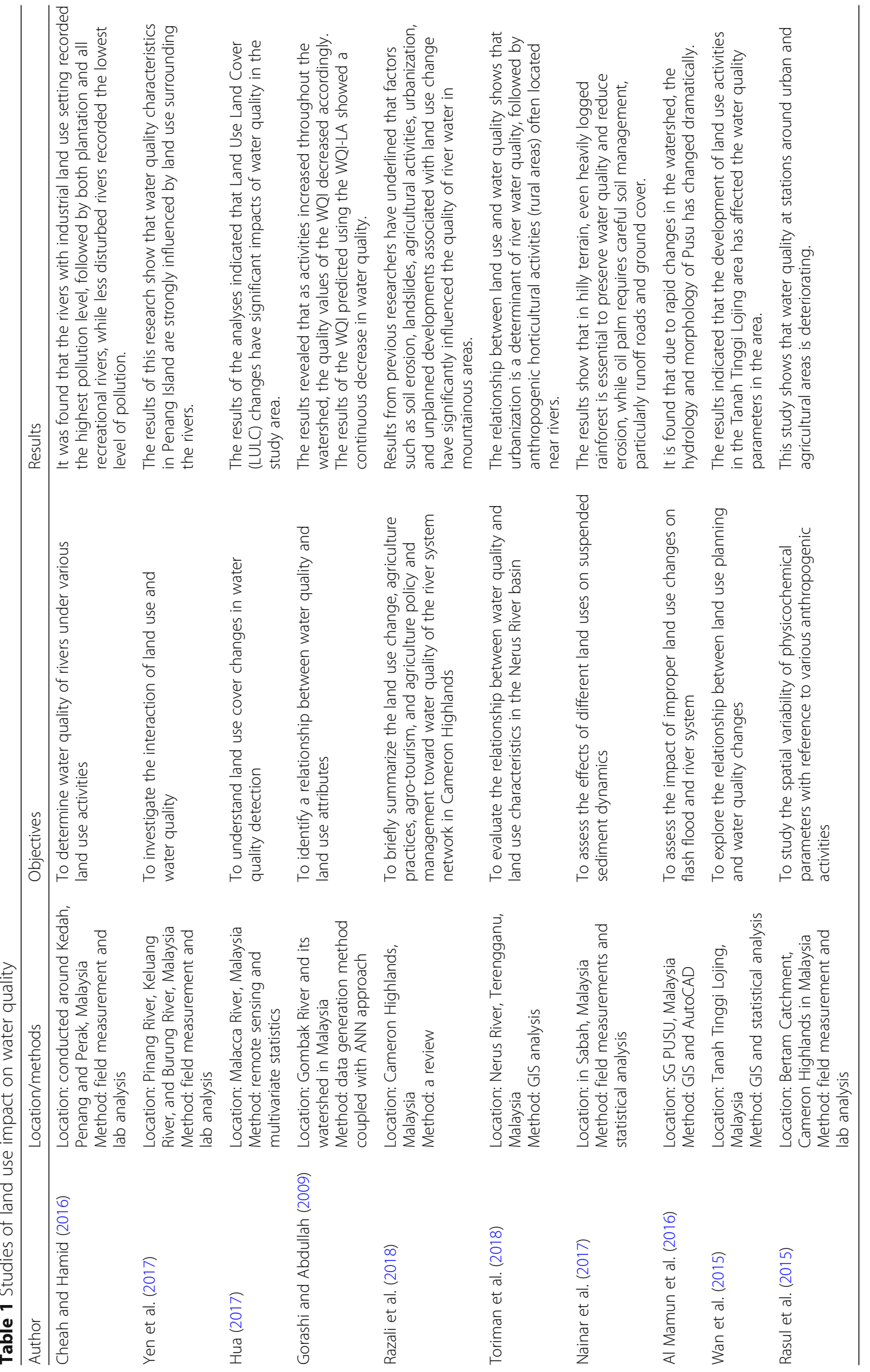




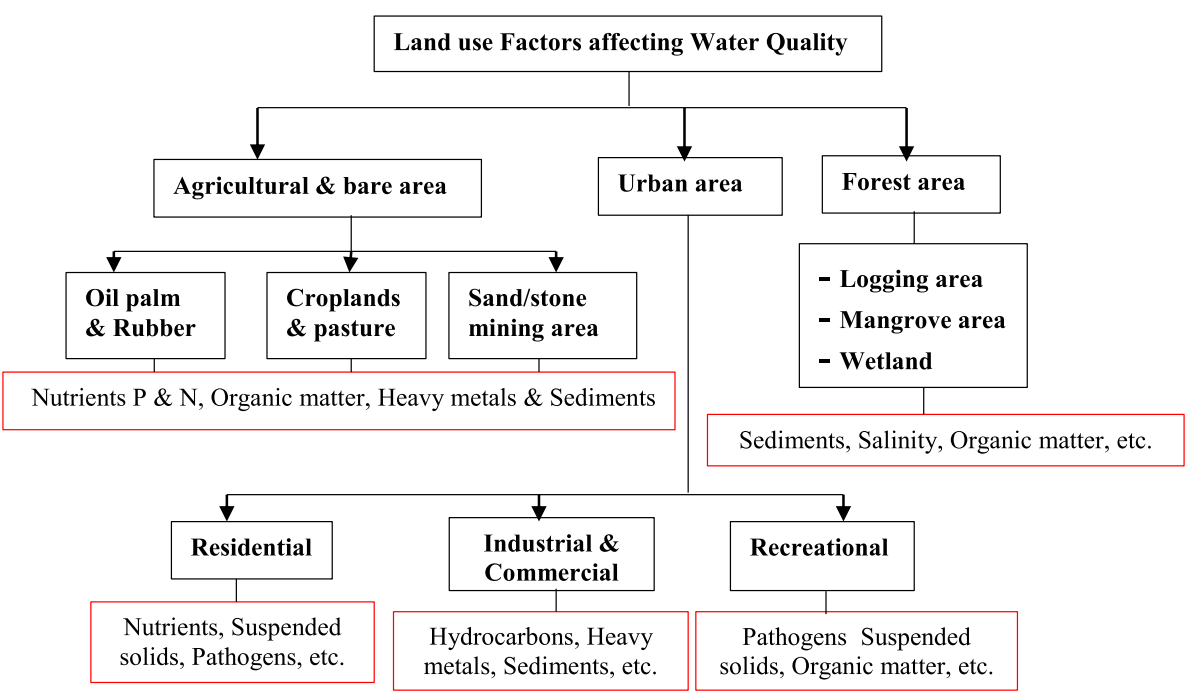

Fig. 2 Land use factors affecting water quality

model building, calibration, and validation process (Giri and Qiu 2016).

\section{Land use factors affecting water quality}

Several techniques have been applied in assessing and understanding the relationship between land use and water quality in different watersheds in Malaysia (Table 1). The results clearly showed that land use activities have significant impacts on water quality (Fig. 2). This is in part due to the rapid and continuous development that the country was experiencing over the last decades. These development activities are sources of water quality degradation in various water bodies through different processes (Table 2). Of the point and non-point source pollution, NPS pollution is a major concern because of its complex nature

Table 2 Significant processes affecting water quality (modified from Bartram et al., 1996)

\begin{tabular}{|c|c|c|c|}
\hline Category & Parameters & Significant process within water body & Water body \\
\hline \multirow[t]{5}{*}{ - Physical } & \multirow{5}{*}{$\begin{array}{l}\text { Temperature, electrical conductivity (EC), total } \\
\text { suspended solids (TSS), turbidity, total dissolved } \\
\text { solids (TDS), etc. }\end{array}$} & Gas exchange with atmosphere & Mostly rivers and lakes \\
\hline & & Volatilization & Mostly rivers and lakes \\
\hline & & Adsorption/desorption & All water bodies \\
\hline & & Heating and cooling & Mostly rivers and lakes \\
\hline & & Diffusion & Lakes and groundwater \\
\hline \multirow[t]{6}{*}{ • Chemical } & \multirow{6}{*}{$\begin{array}{l}\text { Heavy metals, pH, biochemical oxygen demand } \\
(\mathrm{BOD}) \text {, chemical oxygen demand (COD), dissolved } \\
\text { oxygen (DO), nitrate, etc. }\end{array}$} & Photodegradation & Lakes and rivers \\
\hline & & Acid-base reactions & All water bodies \\
\hline & & Redox reactions & All water bodies \\
\hline & & Dissolution of particles & All water bodies \\
\hline & & Precipitation of minerals & All water bodies \\
\hline & & lonic exchange & Groundwater \\
\hline \multirow[t]{4}{*}{ • Biological } & \multirow{4}{*}{$\begin{array}{l}\text { Escherichia coli (E. coli), Ephemeroptera, Trichoptera, } \\
\text { Coliform bacteria, sea urchin, etc. }\end{array}$} & Primary production & Surface waters \\
\hline & & Microbial die-off and growth & All water bodies \\
\hline & & Decomposition of organic matter & Mostly rivers and lakes \\
\hline & & Bioaccumulation & Mostly rivers and lakes \\
\hline \multirow[t]{4}{*}{ - Hydrological } & \multirow{4}{*}{$\begin{array}{l}\text { Water level, depth }(\mathrm{m}) \text {, velocity }(\mathrm{m} / \mathrm{s}) \text {, flow direction, } \\
\text { discharge, etc. }\end{array}$} & Dilution & All water bodies \\
\hline & & Evaporation & Surface waters \\
\hline & & Percolation and leaching & Groundwater \\
\hline & & Suspension and settling & Surface waters \\
\hline
\end{tabular}


(Giri and Qiu 2016) and includes agricultural and urban land use activities, deforestation, and other environmental problems. These effects are generally studied by analyzing the relationships between land use and water quality indicators. Several studies have been conducted to match these indicators (Table 3)

Table 3 Significant land use and water quality parameters used in the previous studies

\begin{tabular}{|c|c|c|c|c|c|c|c|c|c|}
\hline \multirow[t]{2}{*}{ No. } & \multirow[t]{2}{*}{ Author/year } & \multicolumn{4}{|c|}{ Water quality variables } & \multicolumn{4}{|c|}{ Land use variables } \\
\hline & & Physical & Chemical & Biological & Hydrological & Urban & Agricultural & Forest & Others \\
\hline 1. & Gazzaz et al. (2015) & $\cdot$ & $\cdot$ & $\cdot$ & & $\cdot$ & $\cdot$ & $\cdot$ & \\
\hline 2. & Cheah and Hamid (2016) & $\cdot$ & . & & $\cdot$ & $\cdot$ & . & & \\
\hline 3. & Ngah and Yusri (2007) & & $\cdot$ & & $\cdot$ & $\cdot$ & $\cdot$ & $\cdot$ & \\
\hline 4. & Yen et al. (2017) & $\cdot$ & . & & & $\cdot$ & $\cdot$ & - & \\
\hline 5. & Azyana and $\mathrm{Na}$ (2012) & $\cdot$ & $\cdot$ & & & $\cdot$ & $\cdot$ & $\cdot$ & $\cdot$ \\
\hline 6. & Ali (2007) & $\cdot$ & $\cdot$ & & & - & $\cdot$ & . & \\
\hline 7. & Gasim et al. (2017) & $\cdot$ & . & & $\cdot$ & - & $\cdot$ & - & \\
\hline 8. & Gandaseca et al. (2014) & $\cdot$ & $\cdot$ & & & $\cdot$ & $\cdot$ & $\cdot$ & \\
\hline 9. & Juahir et al. (2006) & $\cdot$ & $\cdot$ & & & $\cdot$ & $\cdot$ & $\cdot$ & . \\
\hline 10. & Juahir et al. (2010) & & & & . & . & . & . & . \\
\hline 11. & Hua (2017) & $\cdot$ & $\cdot$ & - & & . & $\cdot$ & & . \\
\hline 12. & Memarian et al. (2014) & & & & $\cdot$ & $\cdot$ & $\cdot$ & $\cdot$ & $\cdot$ \\
\hline 13. & Abas and Hashim (2014) & & & & $\cdot$ & - & & & \\
\hline 14. & Yusoff et al. (2001) ${ }^{a}$ & $\cdot$ & $\cdot$ & & . & & $\cdot$ & - & \\
\hline 15. & Gorashi and Abdullah (2009) & $\cdot$ & $\cdot$ & & & $\cdot$ & & • & \\
\hline 16. & Nik (1988) & & & & . & & . & . & \\
\hline 17. & Vijaindra et al. (2003) & & & & $\cdot$ & . & $\cdot$ & & \\
\hline 18. & Memarian et al. (2013) & $\cdot$ & & & $\cdot$ & $\cdot$ & $\cdot$ & . & . \\
\hline 19. & Nurhidayu et al. (2016) & $\cdot$ & & & . & . & & . & \\
\hline 20. & Sakai et al. (2017) & - & . & - & . & - & . & . & . \\
\hline 21. & Freeman et al. (2008) ${ }^{a}$ & . & & & & . & & . & \\
\hline 22. & Malmer (1996) ${ }^{\mathrm{a}}$ & $\cdot$ & & & $\cdot$ & & & $\cdot$ & \\
\hline 23. & Al-Shami et al. (2011) & $\cdot$ & . & · & $\cdot$ & . & $\cdot$ & & \\
\hline 24. & Toriman et al. (2018) & - & . & . & & . & . & . & . \\
\hline 25. & Nainar et al. (2017) & $\cdot$ & & & $\cdot$ & & $\cdot$ & $\cdot$ & \\
\hline 26. & Al Mamun et al. (2016) & - & . & & . & . & & . & \\
\hline 27. & Kozaki et al. (2016) & & $\cdot$ & & & $\cdot$ & - & $\cdot$ & \\
\hline 28. & Kamarudin et al. (2015) & - & & & . & . & . & . & . \\
\hline 29. & Wan et al. (2015) & - & & & . & . & . & . & . \\
\hline 30. & Chow et al. (2013) & - & - & & $\cdot$ & $\cdot$ & & & \\
\hline 31. & Irvine et al. (2012) ${ }^{a}$ & . & . & . & & . & $\cdot$ & . & \\
\hline 32. & Aweng et al. (2011) & . & . & & & . & - & . & \\
\hline 33. & Yunus et al. (2003) & · & - & & & . & - & . & . \\
\hline 34. & Jamil et al. (2014) & . & . & & . & . & . & . & \\
\hline 35. & Raj (2002) & - & & & . & . & . & . & \\
\hline 36. & Rasul et al. (2015) & - & . & & & . & . & & \\
\hline 37. & Narany et al. (2017) ${ }^{a}$ & . & . & & . & . & . & . & . \\
\hline 38. & Narany et al. (2018) a & & . & & & . & . & & \\
\hline 39. & Ariffin et al. (2016) & & . & & . & & . & & \\
\hline
\end{tabular}


and analyze the cause-and-effect relationship between them. The following sections discuss the correlation between each major land use category and the types of water quality indicators used in the different studies conducted in Malaysia over the years.

\section{Impact of agricultural land use on water quality}

The clearing activities of land can lead to increased salinity problems in a catchment and the export of sediments and the decomposition of organic matter in streams which can lead to acidity problems in the catchment (such as low $\mathrm{pH}$, increased total acidity, and mobilization of dissolved heavy metals) (Fig. 2). Stock control activities, such as feedlots, can result in increased organic matter in local streams, which have a similar effect on water quality like a wastewater treatment plant (WADW 2009). As such, most researchers have focused on the effects of agricultural land use on water quality in addressing water quality issues in Malaysia. About $82 \%$ of the articles analyzed in this report involved agricultural activities as a major source of water quality degradation (Table 3), and most studies have addressed this issue in 2015 and 2017 (Fig. 3). The results of the correlation analysis showed that there was a significant positive relationship between agricultural activities and the physical and chemical characteristics of water quality (Table 4). The physical parameters identified in the various studies for this research include temperature, electrical conductivity (EC), total suspended solids (TSS), turbidity, and total dissolved solids (TDS), and the chemical parameters include heavy metals, $\mathrm{pH}$, biochemical oxygen demand (BOD), chemical oxygen demand (COD), dissolved oxygen (DO), and nitrate. In addition, these water quality indicators have been the focus of most studies in Malaysia (Fig. 4). This may be due in part to the fact that these parameters are composed of the elements used to determine the status of different water bodies in Malaysia using the DOE Water Quality Index (DOE-WQI). Furthermore, although a positive correlation between agricultural land and the other parameters was observed over the past years, this relationship was not significant across the different studies (Table 4).

\section{Impact of urban land use on water quality}

Water quality is affected by human interference related to urbanization, such as industrialization and the increase in housing development (Fig. 2). In Malaysia, many researchers have studied the impact of urban land use on water quality over the last decade. As such, agricultural and urban land use factors have been the focus of most studies dealing with water quality in the country. The results of the papers analyzed in this study indicated that the main sources of water quality degradation in urban areas include various activities, such as residential, industrial, and commercial, as well as recreational activities (Fig. 2). Consequently, urban development has become a significant predictor of water quality changes in Malaysian rivers (Fig. 3). For this reason, Azyana and $\mathrm{Na}$ (2012) concluded, after their study on the degradation of water quality in the Kinta River, that developed lands were found to be the best indicator for predicting water quality degradation. Nurhidayu et al. (2016) suggested a more effective land use planning method that takes into account the impacts of accelerated sediments from converted land use to ensure the protection of the environment.

However, based on the significance of data used in the past studies, urban land use showed the most significant positive relationship only with hydrological parameters (Table 4). These parameters mainly include water level and depth, velocity, flow direction, and discharge, in relation to water pollutants' fate and erosion patterns. The strong positive correlation between urban land use and

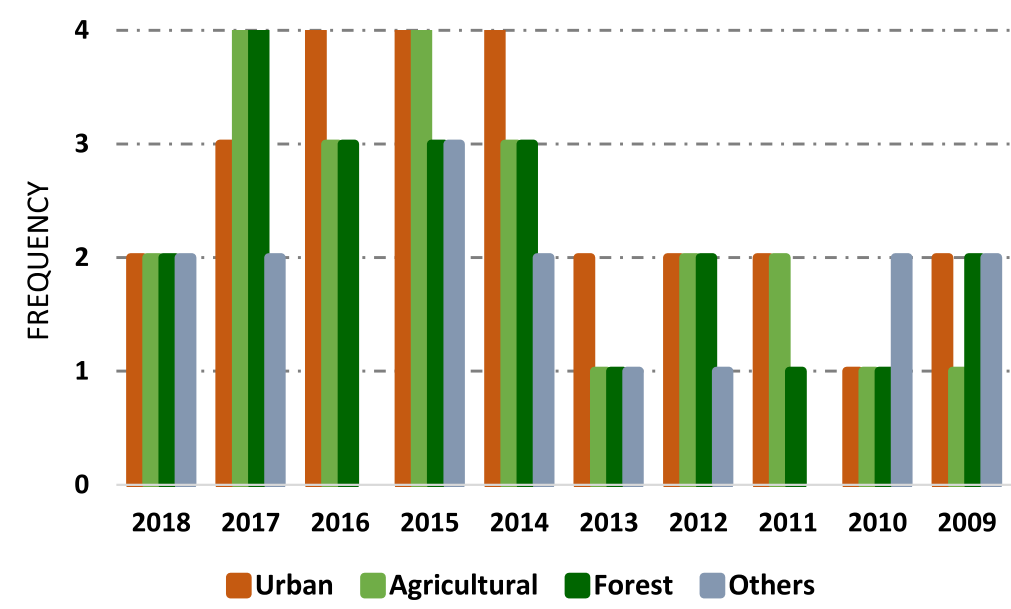

Fig. 3 Frequency of land use attributes used in different studies in Malaysia 
Table 4 Spearman correlation between land use and water quality indicators used in the previous studies

\begin{tabular}{lllllllll}
\hline Variables & Urban & Agricultural & Forest & Others & Physical & Chemical & Biological & Hydrological \\
\hline Urban & 1 & 0.606 & 0.724 & -0.133 & 0.558 & 0.536 & -0.180 & 0.714 \\
Agricultural & 0.606 & 1 & 0.756 & 0.111 & 0.707 & 0.667 & 0.595 & 0.490 \\
Forest & 0.724 & 0.756 & 1 & 0.228 & 0.770 & 0.764 & 0.220 & 0.508 \\
Others & -0.133 & 0.111 & 0.228 & 1 & -0.101 & -0.263 & 0.151 & -0.109 \\
Physical & 0.558 & 0.707 & 0.770 & -0.101 & 1 & 0.901 & 0.438 & 0.495 \\
Chemical & 0.536 & 0.667 & 0.764 & -0.263 & 0.901 & 1 & 0.425 & 0.310 \\
Biological & -0.180 & 0.595 & 0.220 & 0.151 & 0.438 & 0.425 & 1 & -0.183 \\
Hydrological & 0.714 & 0.490 & 0.508 & -0.109 & 0.495 & 0.310 & -0.183 & 1 \\
\hline
\end{tabular}

Values in italics are different from 0 with a significance level alpha $=0.05$

hydrological parameters, as identified in this study, confirms the finding of previous studies indicating the cause-effect relationship between urban developments and changes in the hydrological regime.

\section{Impact of forest land use on water quality}

Without human intervention activities, natural forests would have no significant adverse impacts on water quality. In fact, these forests contribute to maintaining the quality of surface water in particular. As such, in their study, Nainar et al. (2017) underlined some contributions of rainforest to the preservation of water quality and reduced erosion. However, the results of many articles analyzed in this study indicated that forest areas are gradually decreasing in Malaysia, mainly due to the conversion actions to either agricultural or urban development activities. For this reason, about $77 \%$ of the reports analyzed in the present study have more or less focused on the effects of deforestation (logging activities) to surface water quality in Malaysia (Table 3). The results of correlation analysis between land use and water quality attributes also showed a significant positive association of forest land areas and changes in physical and chemical parameters of water quality in the country (Table 4). In addition, there was also a significant positive correlation between urban, agricultural, and forest areas on the one hand, and between physical and chemical indicators of water quality on the other hand. Indeed, these variables were primarily responsible for understanding the effects of land use on water quality in Malaysia. However, many researchers suggested sustainable management of mangrove areas and logging activities in order to achieve sustainable development and a better understanding of effective water conservation and management.

\section{Conclusion}

Factors affecting water quality in developing countries are complex and their sources have been described in many literatures. However, most of these literatures have not touched on their processes, especially with regard to surface water pollution. Therefore, this research was needed to review and analyze the existing studies in order to provide a clear summary of the main sources of water pollution and to understand the processes involved. The results of the reviewed literatures revealed

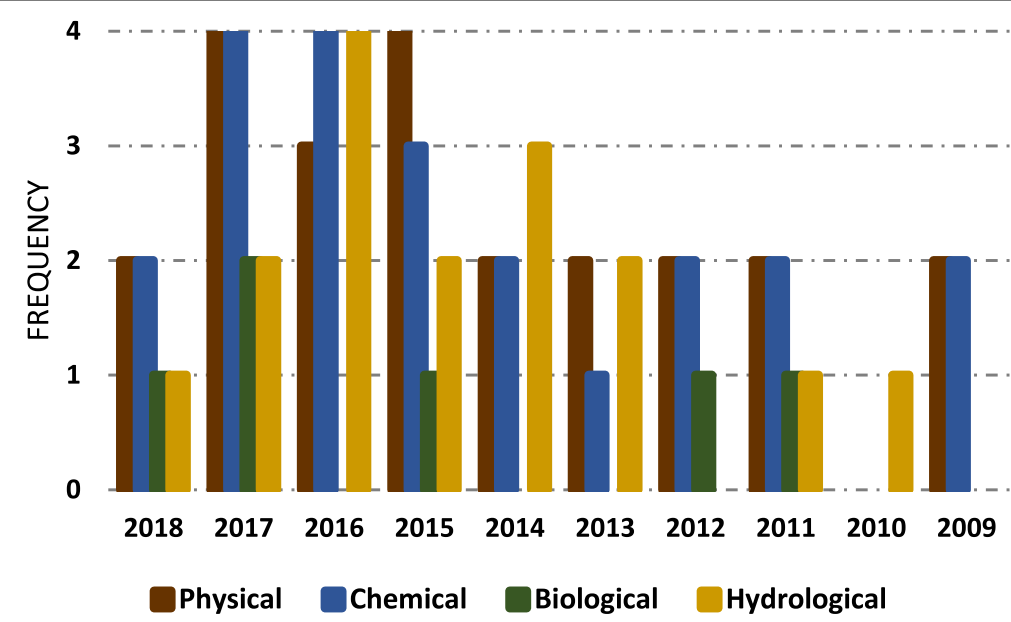

Fig. 4 Frequency of water quality parameters used in different studies in Malaysia 
that urban development, agricultural activities, and forest degradation are the main sources of water quality deterioration in Malaysia, with $87 \%$ of studies indicating the impact of urban land use, $82 \%$ of agricultural land use, $77 \%$ of forest land use, and $44 \%$ of other land uses. As a result of human activities, the effects of these land use factors on water quality have been understood through the processes linking them to the water quality indicators as described in the previous sections. For example, urban land use activities have a greater impact on water quality by altering hydrological processes, and agricultural activities and forest degradation were strongly correlated with physical and chemical parameters of water quality. This understanding of the relationship between land use and water quality would facilitate the management not only of the main sources of water pollution, but also of the processes involved.

\section{Abbreviations}

DOE: Department of Environment; GIS: Geographic information systems; GPR: Groundwater pollution risk; LU/WQ: Land use/water quality; LULC: Land Use Land Cover; NPS: Non-point sources; UPM: Universiti Putra Malaysia; WQI: Water Quality Index

\section{Acknowledgements}

The authors thank the Sultan Abdul Samad Library of UPM for providing the resources used in this study.

\section{Funding}

Financial assistance for this research was provided by the Department of Environmental Sciences, Faculty of Environmental Studies, Universiti Putra Malaysia (UPM), Malaysia.

\section{Availability of data and materials}

All the data used and analysed in this study are included in this manuscript.

\section{Authors' contributions}

NRJ supervised the research and approved the findings. CM carried out the research and analyzed and reported findings. AFBA verified the reference sources and approved the analysis procedures and the results. All authors read and approved the final manuscript.

\section{Ethics approval and consent to participate}

Not applicable.

\section{Consent for publication}

Not applicable.

\section{Competing interests}

The authors declare that they have no competing interests.

\section{Publisher's Note}

Springer Nature remains neutral with regard to jurisdictional claims in published maps and institutional affiliations.

\section{Author details}

${ }^{1}$ Faculty of Environmental Studies, Universiti Putra Malaysia UPM, 43400 Serdang, Selangor, Malaysia. ${ }^{2}$ Department of Biological and Agricultural Engineering, Faculty of Engineering, Universiti Putra Malaysia (UPM), 43400 Serdang, Selangor, Malaysia.
Received: 20 December 2018 Accepted: 27 February 2019

Published online: 10 April 2019

\section{References}

Abas AA, Hashim M (2014) Change detection of runoff-urban growth relationship in urbanised watershed. IOP Conf Ser Earth Environ Sci 18:012040. https://doi. org/10.1088/1755-1315/18/1/012040

Abdulkareem JH, Pradhan B, Sulaiman WNA, Jamil NR (2018) Review of studies on hydrological modelling in Malaysia. Model Earth Syst Environ 4:15771605. https://doi.org/10.1007/s40808-018-0509-y

Al Mamun A, Salleh MN, Nuruzzaman M, Dom NM, Amin MZ, Eusuf MA, Chowdhury AJ (2016) Impact of improper landuse changes on flash flood and river system—a case of Sg Pusu. ARPN J. Eng. Appl. Sci 11:5372-5379

Ali MZ (2007) The application of the artificial neural network model for river water quality classification with emphasis on the impact of land use activities: a case study from several catchments in Malaysia. PhD thesis

Al-Shami SA, Rawi CS, Ahmad AH, Hamid SA, Nor SA (2011) Influence of agricultural, industrial, and anthropogenic stresses on the distribution and diversity of macroinvertebrates in Juru River Basin, Penang, Malaysia. Ecotoxicol Environ Saf 74:1195-1202. https://doi.org/10.1016/J.ECOENV.2011. 02.022

Anderson J (1976) A land use and land cover classification system for use with remote sensor data. Vol. 964. US Government Printing Office, USA.

Ariffin SM, Zawawi MAM, Man HC (2016) Evaluation of groundwater pollution risk (GPR) from agricultural activities using DRASTIC model and GIS. IOP Conf Ser Earth Environ Sci 37:012078. https://doi.org/10.1088/1755-1315/37/1/012078

Aweng ER, Ismid MS, Maketab M (2011) The effect of land uses on physicochemical water quality at three rivers in Sungai Endau watershed. Aust J Basic Appl Sci 5:923-932

Azyana Y, Na NN (2012) Land use and catchment size/scale on the water quality deterioration of Kinta River, Perak, Malaysia. Malaysian J Sci 31:121-131. https://doi.org/10.22452/mjs.vol31no2.4

Baird C, Jennings M, Ockerman D, Dybala T (1996) Charaterization of nonpoint sources and loadings to the Corpus Christi Bay National Estuary Program study area. Final report. Natural Resources Conservation Service, Washington, DC

Baker A (2003) Land use and water quality. Hydrol Process 17:2499-2501. https:// doi.org/10.1002/hyp.5140

Bartram J, Ballance R (1996) Water quality monitoring - a practical guide to the design and implementation of freshwater quality studies and monitoring programmes. United Nations Environment Programme and the World Health Organization

Buck O, Niyogi DK, Townsend CR (2004) Scale-dependence of land use effects on water quality of streams in agricultural catchments. Environ Pollut 130:287299. https://doi.org/10.1016/J.ENVPOL.2003.10.018

Cheah EH, Hamid SA (2016) Determination of water quality of rivers under various land use activities using physico-chemical parameters and bacterial populations in Northern Peninsular Malaysia. wetlands.iga.ac.cn. https://doi. org/10.13248/j.cnki.wetlandsci.2016.06.005

Chow MF, Yusop Z, Shirazi SM (2013) Storm runoff quality and pollutant loading from commercial, residential, and industrial catchments in the tropic. Environ Monit Assess 185:8321-8331. https://doi.org/10.1007/s10661-013-3175-6

Encyclopedia.com (2009) Land Use Environmental Science: In Context. https:// www.encyclopedia.com/environment/energy-government-and-defensemagazines/land-use. Accessed 9 Aug 2018

Freeman AS, Short FT, Isnain I, Razak FA, Coles RG (2008) Seagrass on the edge: land-use practices threaten coastal seagrass communities in Sabah, Malaysia. Biol Conserv 141:2993-3005. https://doi.org/10.1016/J.BIOCON.2008.09.018

Gandaseca S, Rosli N, Pazi AM, Arianto Cl (2014) Effects of land use on river water quality of Awat-Awat Lawas Mangrove Forest Limbang Sarawak Malaysia. Int J Phys Sci Full Length Res Pap 9:386-396. https://doi.org/10.5897/IJPS2014.4179

Gasim MB, Toriman ME, Rahim SA, Islam MS, Che TC, Juahir H (2017) Hydrology, water quality and land-use assessment of Tasik Chini's feeder rivers, Pahang, Malaysia. Geografia 2:1

Gazzaz NM, Yusoff MK, Ramli MF, Juahir H, Aris AZ (2015) Artificial neural network modeling of the water quality index using land use areas as predictors. Water Environ Res 87:99-112

Giri S, Qiu Z (2016) Understanding the relationship of land uses and water quality in twenty first century: a review. J Environ Manag 173:41-48. https://doi.org/ 10.1016/J.JENVMAN.2016.02.029

Gorashi F, Abdullah A (2009) An intedrated approach for the prediction of water quality index based on land use attributes using data generation method 
and back propagagtion network algorithm. Planning Malaysia 7. https://doi org/10.21837/pmjournal.v7.i1.73

Hua AK (2017) Land use land cover changes in detection of water quality: a study based on remote sensing and multivariate statistics. J Environ Public Health 2017:1-12. https://doi.org/10.1155/2017/7515130

Irvine K, Vermette S, Firuza BM (2012) The "black waters" of Malaysia: tracking water quality from the peat swamp forest to the sea. In: 2012 International Symposium on Geomatics for Integrated Water Resource Management. IEEE, pp 1-6

Jamil NR, Ruslan MS, Toriman ME, Idris M, Razad AA (2014) Impact of landuse on seasonal water quality at highland lake: a case study of Ringlet Lake, Cameron Highlands, Pahang. In: From sources to solution. Springer Singapore, Singapore, pp 409-413

Juahir H, Zain SM, Aris AZ, Yusof MK, Samah MA, Mokhtar M (2010) Hydrological trend analysis due to land use changes at Langat River Basin. Environ Asia 3: 20-31

Juahir H, Zain SM, Jaafar MN, Majeed ZA, Toriman ME (2006) Land use temporal changes: a comparison using GIS analysis and statistical analysis on the impact of water quality at Langat River Basin, Malaysia

Kamarudin MK, Toriman ME, Rosli MH, Juahir H, Aziz NA, Azid A, Zainuddin SF, Sulaiman WN (2015) Analysis of meander evolution studies on effect from land use and climate change at the upstream reach of the Pahang River, Malaysia. Mitig Adapt Strateg Glob Chang 20:1319-1334. https://doi.org/10. 1007/s11027-014-9547-6

Kozaki D, Rahim MH, Ishak WM, Yusoff MM, Mori M, Nakatani N, Tanaka K (2016) Assessment of the river water pollution levels in Kuantan, Malaysia, using ion-exclusion chromatographic data, water quality indices, and land usage patterns. Air Soil Water Res 9:ASWR.S33017. https://doi.org/10.4137/ASWR. S33017

Li S, Gu S, Liu W, Han H, Zhang Q (2008) Water quality in relation to land use and land cover in the upper Han River Basin, China. Catena 75:216-222. https://doi.org/10.1016/J.CATENA.2008.06.005

Malaysia DOE (2018) Marine and water quality monitoring https://www.doe.gov. my/portalv1/en/info-umum/pemantauan-kualiti-air-dan-marin/303. Accessed 28 Jul 2018

Malmer A (1996) Hydrological effects and nutrient losses of forest plantation establishment on tropical rainforest land in Sabah, Malaysia. J Hydrol 174 129-148. https://doi.org/10.1016/0022-1694(95)02757-2

Memarian H, Balasundram SK, Abbaspour KC, Talib JB, Boon Sung CT, Sood AM (2014) SWAT-based hydrological modelling of tropical land-use scenarios. Hydrol Sci J 59:1808-1829. https://doi.org/10.1080/02626667.2014.892598

Memarian H, Balasundram SK, Talib JB, Teh Boon Sung C, Mohd Sood A, Abbaspour KC (2013) KINEROS2 application for land use/cover change impact analysis at the Hulu Langat Basin, Malaysia. Water Environ J 27:549560. https://doi.org/10.1111/wej.12002

Nainar A, Bidin K, Walsh RP, Ewers RM, Reynolds G (2017) Effects of different landuse on suspended sediment dynamics in Sabah (Malaysian Borneo)-a view at the event and annual timescales. Hydro Res Let 11:79-84. https://doi.org/10. 3178/hrl.11.79

Narany TS, Aris AZ, Sefie A, Keesstra S (2017) Detecting and predicting the impact of land use changes on groundwater quality, a case study in Northern Kelantan, Malaysia. Sci Total Environ 599-600:844-853. https://doi. org/10.1016/j.scitotenv.2017.04.171

Narany TS, Sefie A, Aris AZ (2018) The long-term impacts of anthropogenic and natural processes on groundwater deterioration in a multilayered aquifer. Sci Total Environ 630:931-942. https://doi.org/10.1016/j.scitotenv.2018.02.190

Ngah C, Yusri MS (2007) Impact of land use change on water yield and water quality in peninsular Malaysia (Doctoral dissertation, Loughborough University).

Nik AR (1988) Water yield changes after forest conversion to agricultural landuse in Peninsular Malaysia. J Trop For Sci 1:67-84

Nurhidayu S, Faizalhakim M, Shafuan A (2016) Long-term sediment pattern of the Selangor River Basin, Malaysia impacted by land-use and climate changes

Raj JK (2002) Land use changes, soil erosion and decreased base flow of rivers at Cameron Highlands, Peninsular Malaysia

Rasul MG, Islam MS, Alam L, bin Mokthar M (2015) Effects of Anthropogenic Impact on Water Quality in Bertam Catchment, Cameron Highlands, Malaysia. Int J Ecol Environ Sci 41(1-2):75-86.

Razali A, Ismail SN, Awang S, Praveena SM, Abidin EZ (2018) Land use change in highland area and its impact on river water quality: a review of case studies in Malaysia. Ecol Process 7:19. https://doi.org/10.1186/s13717-018-0126-8
Rodrigues V, Estrany J, Ranzini M, de Cicco V, Martín-Benito JM, Hedo J, LucasBorja ME (2018) Effects of land use and seasonality on stream water quality in a small tropical catchment: the headwater of Córrego Água Limpa, São Paulo (Brazil). Sci Total Environ 622-623:1553-1561. https://doi.org/10.1016/J. SCITOTENV.2017.10.028

Sakai N, Alsaad Z, Thuong NT, Shiota K, Yoneda M, Mohd MA (2017) Source profiling of arsenic and heavy metals in the Selangor River basin and their maternal and cord blood levels in Selangor State, Malaysia. Chemosphere 184:857-865. https://doi.org/10.1016/J.CHEMOSPHERE.2017.06.070

Tong STY, Chen W (2002) Modeling the relationship between land use and surface water quality. J Environ Manag 66:377-393. https://doi.org/10.1006/ JEMA.2002.0593

Toriman ME, Alssgeer HM, Gasim MB, Kamarudin KA, Daw MM, Alabyad LO (2018) Impacts of land-use changes on water quality by an application of GIS analysis: a case study of Nerus River, Terengganu, Malaysia. Int J Eng Technol 7:155-164. https://doi.org/10.14419/ijet.v7i3.14.16877

Tu J (2011) Spatial and temporal relationships between water quality and land use in northern Georgia, USA. J Integr Environ Sci 8:151-170. https://doi.org/ 10.1080/1943815X.2011.577076

Vijaindra M, Ravindranath S, Nathawat M (2003) GIS application in evaluating land use-land cover change and its impact on hydrological regime in Langat River Basin, Malaysia. geospatialworld.net

Wan AY, Mokhtar J, Mohd KA, Mohd ET (2015) Land exploration study and water quality changes in Tanah Tinggi Lojing, Kelantan, Malaysia. Malaysian J Analyt Sci. 19(5):951-959

Western Australia Department of Water (2009) Water quality monitoring program design - a guideline for field sampling for surface water quality

Yen LJ, Matsumoto Y, Yin CS, Wern HC, Inoue T, Usami A, Iwatsuki E, Yagi A (2017) Characteristics of water quality of rivers related to land-use in Penang Island Malaysia. AIP Conference Proceedings 1892:040008

Yunus AJM, Nakagoshi N, Ibrahim AL (2003) Application of GIS and remote sensing for measuring and evaluating land-use change and its impact on water quality in the Pinang River watershed. Ecol Civ Eng 6:97-110. https:// doi.org/10.3825/ece.6.97

Yusoff MK, Heng SS, Majid NM, Mokhtaruddin AM, Hanum IF, Alias MA, Kobayashi $S$ (2001) Effects of different land use patterns on the stream water quality in Pasoh, Negeri Sembilan, Malaysia. In Rehabilitation of degraded tropical forest ecosystems: workshop proceedings, 2-4 November 1999, Bogor, Indonesia. CIFOR, Bogor

\section{Submit your manuscript to a SpringerOpen ${ }^{\circ}$ journal and benefit from:}

- Convenient online submission

- Rigorous peer review

- Open access: articles freely available online

High visibility within the field

- Retaining the copyright to your article

Submit your next manuscript at $\boldsymbol{\nabla}$ springeropen.com 